University of Tulsa College of Law

TU Law Digital Commons

Articles, Chapters in Books and Other Contributions to Scholarly Works

2008

\title{
Bottom-Up Lawmaking: The Private Origins of Transnational Law
}

Janet K. Levit

Follow this and additional works at: http://digitalcommons.law.utulsa.edu/fac_pub

\section{Recommended Citation}

15 Ind. J. Global Legal Stud. 49 (2008).

This Article is brought to you for free and open access by TU Law Digital Commons. It has been accepted for inclusion in Articles, Chapters in Books and Other Contributions to Scholarly Works by an authorized administrator of TU Law Digital Commons. For more information, please contact daniel-bell@utulsa.edu. 


\title{
Bottom-Up Lawmaking: The Private Origins of Transnational Law
}

\author{
Janet Koven Levit*
}

\begin{abstract}
This article introduces one way in which the private sector makes law-bottom-up transnational lawmaking. While this article explores one example in depth - the Berne Union's regulation of export credit insurance-it concludes that bottom-up lawmaking peppers our legal landscape in a profound and largely unacknowledged way. More specifically, this article discusses how the private sector engages in international lawmaking and contemplates the normative implications of privatized transnational lawmaking.
\end{abstract}

\section{INTRODUCTION}

Two interrelated questions framed the deliberations from the Indiana Journal of Global Legal Studies symposium on "Democracy and the Transnational Private Sector:" 1) to what extent is the transnational private sector assuming a lawmaking role that previously belonged to the state, or some other official lawmaking entity? and 2) assuming that the empirical evidence bears fruit, what normative challenges does this ascendance of the transnational private sector pose in terms of democracy and democratic legitimacy? In this brief article, I offer my work on bottom-up transnational lawmaking as a window into both of these questions.

Part I of this article addresses the underlying empirical questions: 1) how, in practice, does the private sector engage in international lawmaking? and 2) how

* Professor of Law, University of Tulsa College of Law; Yale Law School (J.D., 1994); Yale University (M.A., 1994); Princeton University (A.B., 1990). This article is based partly on a presentation I gave at the Indiana Journal of Global Legal Studies symposium, "Democracy and the Transnational Private Sector," and partly on an earlier article I wrote, Bottom-Up Transnational Lawmaking: Reflections on the New Haven School of International Law, 32 YALE J. INT'L L. 393 (2007).

1. Held April 12-13, 2007 at Indiana University School of Law-Bloomington.

Indiana Journal of Global Legal Studies Vol. 15 \#1 (Winter 2008)

OIndiana University School of Law 
widespread is the phenomenon? Part I recounts an instance of bottom-up transnational lawmaking as illustrative of how the private sector engages in lawmaking. In short, bottom-up lawmaking is a soft, unchoreographed process, often under private-sector tutelage, that produces hard legal results. While the story at the heart of Part I unfolds in the relatively niche world of international trade finance, Part I concludes with numerous and diverse bottom-up lawmaking examples, thereby suggesting that private-sector-led, bottom-up lawmaking occurs much more than we suspect.

Using bottom-up lawmaking as the lens, Part II of this article contemplates the normative implications of privatized transnational lawmaking. In reality, these private, bottom-up lawmaking communities tend to be very club-like, with secrecy and exclusivity assuming normative status within the group. In light of this secretive penchant, Part II asks whether private transnational lawmaking is a legitimate route to law. In contemplating answers, this article measures legitimacy not only against democratic norms (accountability, transparency, etc.), but also against efficacy of legal outcomes and policies. Yet, neither "opening" the lawmaking process (and thus more closely approximating democratic lawmaking) nor calibrating the efficacy of ensuing regulation satisfactorily answers the legitimacy critique. Instead, this article suggests that legitimacy may unduly preoccupy our attention, for the bottom-up lawmaking process itself may correct many of the deficits.

\section{Bottom-Up Lawmaking Happens}

\section{A. Export Credit Insurance: A Bottom-Up Lawmaking Tale}

My work on bottom-up lawmaking, which to date has focused on the realm of international trade and finance, ${ }^{2}$ suggests that private parties and other "informal" or "unofficial" lawmaking communities" indeed play a significant role in

2. See, e.g., Janet Koven Levit, $A$ Bottom-Up Approach to International Lawmaking: The Tale of Three Trade Finance Instruments, 30 Y ALE J. INT'L L. 125, 172-73 (2005) (noting that norms cross the soft-law/hard-law divide but without explaining in any robust way the push or the pull).

3. As a point of definitional clarity, this article uses the terms "informal" or "unofficial" lawmaking community to refer to a transnational group, often institutionalized, which is neither constituted by treaty, nor any other legally binding instrument, thereby lacking direct authority to make legally binding law. This article employs the term "treaty," as in The Vienna Convention on the Law of Treaties, May 23, 1969, 1155 U.N.T.S. 331, 333 art. 2 (“'Treaty' means an international agreement concluded between States in written form and governed by international law."). As such, this article employs, but does not endorse, the formality of the legally "binding" versus "nonbinding" dichotomy. "Binding international law" includes: 1) a treaty or other international agree- 
constituting international (or transnational) law. Consider the World Trade Organization Agreement on Subsidies (Agreement on Subsidies). ${ }^{4}$ On its surface, the agreement is a "top-down," government-driven effort to solve the endemic cooperation, coordination, and free-riding problems of creating an "even playing field" for exporters. The Agreement on Subsidies promises to curb (in trade language, discipline) the use of trade-distorting subsidies in the name of free trade. Where did these rules come from? Were they the result of choreographed state bargaining and diplomatic wrangling? Perhaps some of the rules in the Agreement on Subsidies were, indeed, a product of such top-down negotiations.

Yet, an alternative account of the Agreement on Subsidies tells us about the work of private parties and low-level bureaucrats, and starts long before the founding of the World Trade Organization (WTO); it focuses on the rather arcane, technical world of officially supported export credit, specifically the world of export credit insurance. Export credit insurance functions like automobile insurance, except that the asset the insurance company protects is not a car but rather a trade receivable. With the backing of an insurance provider, an exporter may extend credit to an importer without significantly adding to its risk portfolio. Where liquidity is an issue, a receivable backed by an export credit insurance policy enhances the exporter's ability to monetize the receivable, either by selling it or borrowing against it. Export credit insurance, therefore, is one solution to a recurring exporter problem - how to extend credit to a buyer, who might be thousands of miles away, without choking the seller's working capital and concomitant ability to continue producing and engaging in trade transactions.

So, if these insurance policies are a type of exporter's nirvana, where can you purchase one? Can you go to the State Farm office down the street? Indeed, private insurance companies, such as Chubb, American Insurance Group (AIG), and FCIA issue export credit insurance. Also, government entities-entities known as export credit agencies (ECAs) — participate in the export credit insurance market by issuing export credit insurance to their nationals in the name of supporting and promoting local exports. ${ }^{5}$ ECA-government-participation in the export credit

ment, as defined in the Vienna Convention on the Law of Treaties 2) customary international law; and 3) (and a true third) general principles of law. Restatement Third of Foreign Relations Law $\S$ 102 (1986); Statute of the International Court of Justice, June 26, 1945, art. 38, 59 Stat. 1055 , 33 U.N.T.S. 993.

4. Agreement on Subsidies and Countervailing Measures, Apr. 15, 1994, 1867 U.N.T.S. 155 [hereinafter Agreement on Subsidies].

5. The Export-Import Bank of the United States (Ex-Im Bank) is the U.S. ECA. I was Assistant General Counsel of Ex-Im Bank from 1998-2000, and I not only observed but also partici- 
insurance industry marks it as a potential breeding ground for subsidies and thus a target for some type of transnational coordination and regulation.

Indeed, that is precisely what happened, although a grand ministerial act or the founding of some large WTO-style institution was not the triggering event. ${ }^{6}$ Instead, an export credit insurance regulatory regime was born in 1934 over drinks in a bar in Berne, Switzerland, when a small group of private European export credit insurers decided to pool experiential data regarding claims and recovery experiences in the name of sound insurance practice. This informal gathering gave birth to the Berne Union. Currently, the Berne Union has more than fifty members, public and private, almost all from the Organisation for Economic Co-operation and Development (OECD) or industrialized countries. ${ }^{\text {? }}$

On the surface, the Berne Union initially appears as a mere trade association, in which case its founding would be unexceptional and certainly unworthy of much scholarly scrutiny. However, following World War II, when government ECAs began using export credit insurance as an aggressive backdoor to subsidize exports, ${ }^{8}$ Berne Union members - private insurers and government technocratsdecided to transform the Berne Union from a mere gatherer and disseminator of insurance-related information into a regulator to target abusive and aggressive subsidy practices.

Over the years, the members have used the semiannual Berne Union get-togethers as a focal point to collect and share their practices and approaches to a variety of regulatory questions, and they have codified these in a living document called the "General Understanding." The General Understanding essentially divides the universe of insurable goods and services into seven groups. Within each category, the General Understanding prescribes specific, technical, and at times, cumbersome rules to standardize the type of insurance products that members may offer and circumscribes the terms that such policies may contain. Thus, the General Understanding is a comprehensive regulatory matrix for the export credit

pated in the very lawmaking process that I now recount.

6. For a more extensive treatment of this lawmaking story, see Levit, supra note 2, at 144-57.

7. International Union of Credit \& Investment Insurers, Berne Union Members, http://www .berneunion.org.uk/bu_profiles.htm (last visited Feb. 27, 2008).

8. Peter C. Evans, The Politics of State-Backed Trade Finance: Competition, Collusion and Redistribution in Official Export Credits, 44-48 (June 22, 2004) (unpublished Ph.D. dissertation, Massachusetts Institute of Technology) (on file with author). See also Hugh Dowell, A Brief Historical Note- 62 Years Ago (facsimile sent to author from Berne Union, June 22, 2004) (on file with author).

9. International Union of Credit and Investment Insurers, The Berne Union Agreements, Understandings and Obligations in the Export Credit Insurance Field: General UNDERSTANDING (2001), available at http://www.nexi.go.jp/insurance/ins_berun/pdf/berunl.pdf. 
insurance industry, essentially translating insurers' on-the-ground experiences into a set of technical rules designed to calibrate transactions and discipline ensuing practice, thereby preventing an export credit insurance policy from masking a predatory export subsidy.

Furthermore, Berne Union rules have been quite successful in facilitating over a half-trillion dollars in trade annually while dramatically reducing export credit subsidies. ${ }^{10}$ Accordingly, when the Agreement on Subsidies attempted to draw a line between prohibited export subsidies and other types of permitted government support, it punted on the issue of "officially supported export credit" and instead created a safe harbor around the Berne Union's rules (via another informal "gentleman's agreement" that essentially borrows from the Berne Union's General Understanding). ${ }^{11}$ Thus, the Agreement on Subsidies deems officially supported export credit insurance policy to be a prohibited export subsidy unless it complies with some Berne Union rules.

This Berne Union example offers a glimpse of bottom-up transnational lawmaking at work. It is relatively modest, quiet, and subterranean, grounded in the practitioners (in this case, export credit insurers) who join with others similarly situated in avocation (although often quite distant in location) to share experiences, standardize practice, and codify norms. While these norms are often intended as a form of self-regulation, over time, they embed in a more formal legal system and harden into "law." Thus, whereas top-down lawmaking is a process of law internalized as practice, bottom-up international lawmaking is a soft, unchoreographed process whereby private practices are externalized as law.

\section{B. Bottom-Up Lawmaking Beyond the Berne Union}

While the technicality and obscurity of this Berne Union example may initially strike as a niche outlier, my research shows - and in fact the very advent of

10. Tadao Chino, The Changing Picture, 2005 Berne Union Y.B. 118.

11. The General Understanding rules have been incorporated into the Arrangement on Officially Supported Export Credit [the Arrangement], which is self-referentially a "Gentleman's Agreement," drafted and managed by the Participants Group, an informal "club" of ECA export credit insurers that is loosely affiliated with the Export Credit Group of the OECD. See Organisation for Economic Co-operation and Development [OECD], Arrangement on Officially Supported Export Credits, Doc. TD/PG (2004) 12/REV (Jan. 27, 2005). The Agreement on Subsidies creates a safe harbor for ECAs that comply with the Arrangement. See Agreement on Subsidies, supra note 4 , at annex $I(k)$. For a more detailed discussion of the relationship between the Berne Union rules, the Arrangement, and the Agreement on Subsidies, see Levit, supra note 2, at 156-67. 
this symposium corroborates-that much that we deem to be international law, in fact much that we deem to be domestic law, is simply the tip of the iceberg, masking a profound, bottom-up lawmaking undercurrent that potently shapes our legal landscape. I have told the bottom-up lawmaking story in a variety of contexts-from trade finance to climate change, ${ }^{12}$ using a variety of lawmaking communities, some populated with private actors and some with low-level bureaucrats, some "tightly-knit" and others more diffuse. Perhaps, with this growing body of data, it would be useful and productive to begin thinking about a bottom-up lawmaking typology, roughly dividing instances into three groups: regulation, harmonization (standardization), and epistemic communities.

In addition to this Berne Union example, I have explored other instances of regulatory botrom-up lawmaking, particularly official export guarantees ${ }^{13}$ and the International Chamber of Commerce's role in regulating letters of credit. ${ }^{14}$ Regulatory bottom-up lawmaking occurs when tightly-knit, homogenous communities codify industry norms in an effort to constrain rent-seeking behavior within a group and simultaneously lock in rents for the group. ${ }^{15}$ Typically this process occurs in an institutionalized setting, with many of the trappings of legislative-like decision making. ${ }^{16}$ Yet, these private communities often become lawmakers, sometimes purposefully and sometimes inadvertently, as officialdom defers to the insular community's regulatory choices.

Closely related, harmonization or standardization efforts also may morph into a bottom-up lawmaking exercise. Industry participants and related interest groups often coalesce within a standard-setting body or a trade association to create a floor, or "voluntary" minimum standards, ${ }^{17}$ to which all within the industry should conform. Yet, these "voluntary" standards often become safe harbors in

12. Janet Koven Levit, Bottom-Up Transnational Lawmaking: Reflections on the New Haven School of International Law, 32 YALE J. INT'L L. 393 (2007).

13. See generally Janet Koven Levit, The Dynamics of International Trade Finance Regulation: The Arrangement on Officially Supported Export Credits, 45 HARv. INT'L L. J. 65 (2004).

14. Janet Koven Levit, Bottom-Up Lawmaking Through a Pluralist Lens: The ICC Banking Commission and the Transnational Regulation of Letters of Credit, 58 EMORY L.J. (forthcoming 2008).

15. See generally Robert B. Ahdieh, The Role of Groups in Norm Transformation: A Dramatic Sketch, in Three Parts, 6 CHI. J. INT'L L. 231 (2005).

16. See, e.g., Paul B. Stephan, Accountability and International Lawmaking: Rules, Rents and Legitimacy, 17 Nw. J. INT'L L. \& Bus. 681, 700-02 (1996).

17. These standards are "voluntary" in the formal legal sense, meaning that legal sanctions will not attach to defection. However, if an industry actor decides not to comply with the standard, then it bears a significant risk of market ostracism. 
formal international agreements (i.e., compliance with the standard assures compliance with the agreement) and thus approximate binding, formal law. ${ }^{18}$

Epistemic bottom-up lawmaking occurs in a more atomistic, less coordinated, fashion, when, in the absence of top-down regulation, various issue-based constituencies nonetheless abide by relatively similar norms that, in and of themselves, define an epistemic community and exert pressure on formal law. Thus, I have argued that normative pressure for climate change regulation, as well as government mandates of corporate social responsibility regulation, flows from such epistemic communities. ${ }^{19}$

Yet, at its core, these diverse bottom-up lawmaking stories share two defining characteristics. First, the "bottom-up" label grounds the normative process in both public and private practitioners, including those motivated by altruism and those motivated by profit, who join with others similarly situated in avocation to share experiences and standardize practices toward shared goals. "Practitioner," as used in the bottom-up lawmaking context, is a deliberately broad term, used loosely to describe those on-the-ground, armed with intimate knowledge of their niche trade and/or interest areas, who embody norms rooted in nitty-gritty technicalities rather than the winds of geopolitics and diplomacy.

18. See, for example, the relationship between the International Organization for Standardization (ISO) and various World Trade Organization agreements. For instance, the WTO Agreement on Technical Barriers to Trade (TBT Agreement) assures that technical standards are not a mask for predatory restraints on trade. Annex 3 of the TBT Agreement offers a Code of Good Practice for the Preparation, Adoption and Application of Standards (the TBT Code of Good Practice). The TBT Agreement requires all member states to adopt the TBT Code of Good Practice vis-à-vis central government activities and strongly encourages adoption at the sub-state, regional, and local level. Importantly, the TBT Code of Good Practice states that " $[\mathrm{w}]$ here international standards exist or their completion is imminent, the standardizing body shall use them, or the relevant parts of them, as a basis for the standards it develops." TBT Agreement, Annex 3, art. F. Thus, international standards, with explicit reference to the International Organization for Standardization and the International Electrotechnical Commission, become a type of baseline mandate for WTO members. Likewise, the WTO Agreement on the Application of Sanitary and Phytosanitary Measures, defers to several quasi-public standard setting bodies, Codex Alimenterius, International Office of Epizootics, and the relevant international and regional organizations operating within the framework of the International Plant Protection Convention. See generally ISO/IEC Information Centre, WTO, ISO, IEC and World Trade, http://www.standardsinfo.net/info/livelink/fetch/2000/148478/6301438/inttrade.html (last visited Feb. 28, 2008).

19. Janet K. Levit, International Law Happens (Whether the Executive Likes It Or Not), in SELA 2006: El Poder Ejecutivo (Roberto Saba ed., forthcoming 2007) (published in Spanish) (exploring bottom-up lawmaking as an alternative to state-made law in climate change regulation, as well as human rights, i.e., corporate social responsibility), available at http://law.bepress.com/cgi/ viewcontent.cgi article $=7853$ \& content $=$ expresso. See also Levit, supra note 12 . 
Second, bottom-up transnational lawmaking joins two interrelated subprocesses: 1) an informal process of norm creation and 2) a hardening process, whereby official legal systems embed such informal norms, either at the prompting of the informal group or because the norms offer attractive legal solutions to collective action problems. While the first necessarily precedes the second, the two processes become inextricably linked in a loop of interpretation, assessment, and alignment.

Bottom-up lawmaking is thus the antithesis of top-down lawmaking. It is not the world of jet-setting diplomats or Rose Garden signing ceremonies. Nor is it the world of Eric Posner and Jack Goldsmith ${ }^{20}$ who conceive of international law in instrumental terms, as one of many tools that the President may deliberately deploy in furtherance of the "national interest." In the traditional top-down approach, state elites enact rules (typically formal, treaty-based rules) that govern the practices and behavior of those subject to the rules; in this account, lawmaking often ensues well beyond the physical and metaphysical reach of law's subjects. In contrast, a bottomup approach to law focuses on the ways that practices and behaviors of various actors inform and constitute rules, which, in turn, govern such practices and behaviors. The drama in these bottom-up cases is how the informal, practice-based rules escape relatively confined groups and "bubble-up" to become "law."

While bottom-up lawmaking is not top-down lawmaking, it is likewise not mere self-regulation. Onlookers may initially dismiss stories like the one developed in this article as unexceptional examples of private, self-regulatory behavior. From the range of Shasta County, California ${ }^{21}$ to the diamond bourses of New York $^{22}$ to the tuna courts in Tokyo, ${ }^{23}$ many legal scholars and economists discover discrete "private legal systems." These scholars argue that private, "closely knit" homogeneous micro-societies often create their own norms that, at times, trump

20. See generally Jack L. Goldsmith \& Eric A. Posner, The Limits of International Law (2005); Levit, supra note 12.

21. This is a reference to the study of social norms among ranchers and farmers in Shasta County, California that formed the core of Robert Ellickson's classic work, Order without Law 177-78 (1991).

22. See Lisa Bernstein, Opting Out of the Legal System, 21 J. Leg. St. 115 (1992) (discussing the system of "private lawmaking" in the New York Diamond Dealers Club); Lisa Bernstein, Merchant Law in a Merchant Court: Rethinking The Code's Search for Immanent Business Norms, 144 U. PA. L. Rev. 1765 (1996) (National Grain and Feed Association); Lisa Bernstein, Private Commercial Law in the Cotton Industry: Creating Cooperation Through Rules, Norms, and Institutions, 99 MrcH. L. Rev. 1724 (2001) (observing private legal system in the markets for the purchase and sale of cotton).

23. See generally Eric A. Feldman, The Tuna Court: Law and Norms in the World's Premier Fish Market, 94 CAL. L. Rev. 313 (2006). 
state law and, at other times, fill lacunae in state regulation, but nonetheless operate autonomously and beyond the reach of officialdom..$^{24}$ In this scholarly paradigm, a private legal system stands as an alternative to, often in opposition to, the state's official legal apparatus.

Yet, unlike private legal systems, which are largely self-contained and confined, bottom-up lawmaking is a process that traverses legal communities by, in this case, charting a route that links unofficial "law" to officialdom. Thus, while private lawmaking or private legal system scholarship may offer insight into the ways in which group members constitute, interpret, and enforce norms among group members, it does not contemplate, explain, or conceptualize the normative ties between lawmaking communities. Since many private legal system scholars are critical of state incursions in private life because they see themselves as offering a viable (and perhaps preferable) alternative to state law, their analyses often fail to contemplate the extent to which the state, or official lawmaking institutions, borrow from such private law or the extent to which the private lawmaking group lobbies the state to adopt its norms. ${ }^{25}$ Indeed, this article's lawmaking example suggests that, on a transnational plane, a relatively private form of lawmaking may be an interim step on a bottom-up lawmaking process.

\section{A Normative Challenge Posed by Bottom-Up Lawmaking}

\section{A. Closed, Club-Like Lawmaking}

From an empirical perspective, bottom-up lawmaking is a rather diverse, yet ubiquitous, phenomenon that will remain a steadfast, irrepressible feature of the lawmaking landscape. In other words, bottom-up lawmaking happens whether we like it or not. However, once we understand that the transnational private sector often plays a significant, if not definitive, role in the lawmaking process, we must at least contemplate this conference's second normative question-whether bottom-up lawmaking is a legitimate route to law.

24. See Ellickson, supra note 21 at 177-78. For example, despite formal California legal rules to the contrary, informal norms in Shasta County make an animal owner (usually a rancher) liable for the trespass (and ensuing damage) of his animals, except that Shasta County residents essentially absorb de minimis damage, maintaining instead a mental accounting of the damage, on the belief that "what goes around comes around." Id. at 53-54.

25. But see David V. Snyder, Private Lawmaking, 64 Oнı St. L.J. 371, 403-12 (2003) (arguing that the rules that come from private lawmaking groups, like the ICC Banking Commission, are technically law). 
The reality is that these private, bottom-up lawmaking communities tend to be very secretive, exclusive, and club-like. On account of such secrecy, many who read my work condemn bottom-up lawmaking as an illegitimate route to law. It was quite a rude awakening to have my mentor of fifteen years label bottom-up lawmaking a "dangerous threat to democratic principles." ${ }^{.6}$ So, if you would indulge me, I would like to offer a Berne Union anecdote as a window into some of these concerns.

The Berne Union does not publish the General Understanding anywhere, and my quest to find the General Understanding was a modern treasure hunt meeting countless dead-ends and spanning four aggravating months. ${ }^{27}$ Then, unexpectedly, one Berne Union member sent me the General Understanding without any confidentiality stipulations. ${ }^{28}$ Coincidentally, the Secretary General of the Berne Union also granted me a phone interview in which she requested a draft of the article prior to publication, which I provided as a courtesy. After seeing a draft of the article, where I discussed Berne Union rules and criticized its penchant for secretive lawmaking, the Secretary General dangled what I perceived as a veiled threat of legal action against the Yale Journal of International Law and me.

I recall this story to highlight that some of these bottom-up lawmaking communities are black boxes, and club-like secrecy often assumes normative status. My personal frustration was great, but my frustration was merely linked to the fact that I knew I had a story to tell and that I felt excommunicated from a trade finance community in which I had enjoyed membership. The rules themselves, however, had no direct impact on me (or, at least, only the most attenuated effect as a consumer of goods).

Yet, consider the exasperation of government officials in Brazil when in the heat of a dispute with Canada (Canadair), the WTO proclaims that Brazil's (Embraer's) export credit programs essentially must abide by Berne Union rules or run afoul of the Agreement on Subsidies, with the concomitant risk of counter-

26. Indeed, in response to my presentation at the 2006 Seminario en Latinoamérica de Teoría Constitucional y Política (SELA), the presentation that provided the outline for this article, Professor Owen Fiss responds that "democracy must be the bedrock" of law's legitimacy, and that my search for an alternative grounding is a "dangerous" project. See Owen Fiss, Concluding Remarks, Moderator for "Globalization and Executive Power" at Yale Law School's Southern Cone Faculty Research Seminar: Seminario en Latinoamérica de Teoría Constitucional y Política (SELA), Executive Power, Bogota, Colombia (June 9,2006), reprinted in SELA 2006, supra note 19.

27. For a more extensive treatment of my personal interaction with the Berne Union, see Janet Koven Levit, A Cosmopolitan View of Bottom-Up Transnational Lawmaking: The Case of Export Credit Insurance, 51 WaYne L. Rev. 1193, 1204-07 (2005).

28. See Levit, supra note 2, at n.107. See also Levit, supra note 27, at n.51. 
vailing measures. ${ }^{29}$ So what has happened here? An informal, yet exclusive, clublike group of private actors and technocrats from industrialized countries have pooled their practices and experiences and transformed them into rules that essentially prop the cost of export credit insurance (in the name of preventing hidden export subsidies). While the Berne Union initially intended that these rules would apply to members, more formal lawmaking institutions, in this case the OECD and then the WTO, eventually (and perhaps inadvertently) appropriated the rules. Ultimately, these rules have become the law that the WTO uses to decide a dispute against Brazil, but neither Brazil nor any representative from any developing country participated in the formation of these rules, either through direct deliberations or indirect delegations of authority. Thus, in making law behind impervious, fortress-like walls, the Berne Union ultimately creates a disjuncture between law's subjects and lawmakers.

This mismatch - this disjuncture- between law and lawmaker leads Brazil to question the legitimacy of Berne Union rules and the WTO's decision based on these rules. In particular, Brazil resents rules that constrain its ability to promote domestic industry, in this case the aircraft industry, when it "did not bargain for" and had "no voice" in negotiating such rules. ${ }^{30}$

Is Brazil correct? Are Berne Union rules born from a bottom-up lawmaking process to be condemned as illegitimate? Otherwise stated, can law be legitimate if it binds a transnational actor that was alienated from the lawmaking process? Is participation in lawmaking a necessary predicate for law's legitimacy?

Before answering these questions, a bit of definitional clarity is in order. "Legitimacy" is a normative justification for the exercise of authority, highly dependent on context. ${ }^{31}$ For instance, Ruth Grant and Robert Keohane have recently argued that the legitimacy of the exercise of authority on the transnational plane depends on a case-specific cocktail of informal norms (human rights, democratic

29. The reference here is to a recent dispute between Canada and Brazil over Brazil's export credit program in support of Embraer aircraft. WTO Dispute Panel Report on Canada Compliant Concerning Brazil's Export Financing Programme for Aircraft (April 14, 1999) WT/DS46/R, I 7.31. The decision essentially required that Brazil comply with the Arrangement on Officially Supported Export Credit rules, rules which are based in large part on the General Understanding. See supra note 11, for more detailed discussion of the attenuated relationship between the General Understanding and the Agreement on Subsidies.

30. Brazil and other developing countries expressed much concern over being bound by rules made, in large part, by the exclusive club of developed, OECD countries. See Levit, supra note 2, at 204-05 n.328.

31. See Daniel Bodansky, The Legitimacy of International Governance: A Coming Challenge for International Environmental Law, 93 Aм. J. INT'L L. 556, 601 (1999). 
principles, and mechanisms to redress "patterns of extreme economic inequality") and formalized law. ${ }^{32}$ Daniel Bodansky roots legitimacy in the source of purported authority; open, participatory processes; and/or regulatory acumen. ${ }^{33}$ Fundamentally, for Keohane, Grant, and Bodansky, law finds legitimacy either in the nature of the lawmaking process or in the substance of the legal outcome. ${ }^{34}$ Often this distinction is referred to as "input" legitimacy (i.e., following democratic processes and/or legalized procedures; opening lawmaking processes to broad-based participation) and "output" legitimacy (i.e., outcomes that draw upon niche expertise or that satisfy certain substantive regulatory goals), and this article will explore each in turn.

\section{B. Input Legitimacy: Lawmaking Through Democratic Processes}

If we return to this article's example, the gravaman of Brazil's complaint is that, as an issuer of export credit insurance policies, ${ }^{35}$ it had a right to participate in the promulgation of rules that limited its autonomy to use export credit insurance aggressively in support of nationals' exports. Thus, Brazil laments legal restrictions on export credit insurance that are not "of" export credit insurers, "by" export credit insurers, and "for" export credit insurers. ${ }^{36}$ In questioning the legitimacy of law on account of its exclusion from the lawmaking process, Brazil links legitimacy to participation in governance and argues that bottom-up lawmaking presents a classic democratic deficit. ${ }^{37}$

32. Ruth W. Grant \& Robert O. Keohane, Accountability and Abuses of Power in World Politics, 99 A m. Pol. Sci. Rev. 29, 35 (2005).

33. Bodansky, supra note 31, at 611-23 (discussing democracy, public participation, and expertise and distinct bases of legitimacy).

34. As legitimacy is a deeply contested concept, these two definitions are not without competitors and detractors. Yet, as this necessarily brief article purports neither to review "legitimacy" comprehensively nor propose a solution to a well-worn debate, these two conceptions, which float prominently in the transnational lawmaking literature, will serve as a basis for our analysis of the legitimacy of bottom-up lawmaking.

35. Brazil issues export credit insurance through its export credit agency (ECA), the Brazilian Development Bank, BNDES. See BNDES, Export Support, http://www.bndes.gov.br/english/ export_lines.asp (last visited Feb. 28, 2008).

36. This is a reference to Abraham Lincoln's description of democracy as a form of government that is "of the people, by the people, and for the people." Abraham Lincoln, Gettysburg Address (Nov. 19, 1963), http://usinfo.state.gov/usa/infousa/facts/democrac/25.htm.

37. The "democratic deficit" generally refers to institutional and/or structural features of a lawmaking community that result in the lawmaking process falling short of the democratic ideal, most frequently understood in the participatory sense. See, e.g., Francesca E. Bignami, The Demo- 
Yet, mismatch between the "governed" and the "governors" does not per se condemn Berne Union rules, as applied to Brazilian export credit agencies, as undemocratic. Democratic theory has for centuries, since the demise of the Roman city-state assemblies, grappled with ways to assure that governance that was not literally "by the people" remains "of the people." ${ }^{.38}$ While the theoretical underpinnings of democracy undoubtedly remain a point of heated academic and philosophical debate, ${ }^{39}$ and while these different theoretical perspectives reconcile the mismatch between governed and governors in distinct ways, a common bedrock is lawmaker accountability. ${ }^{40}$ "Accountability," like "legitimacy," is a term with contested meaning, although all versions entail the "governed" exercising some type of control, albeit often quite attenuated and weak, over the "governors."

Prominent theories of representative and republican democracy anoint ma-

cratic Deficit in European Community Rulemaking: A Call for Notice and Comment in Comitology, 40 Harv. Int'l L.J. 451 (1999). See generally Alfred C. Aman, The Democracy Deficit: Taming Globalization Through Law Reform (2004).

38. See Robert A. Dahl, On Democracy 7-25 (1998) (noting that "pure" democracy or direct democracy is of the type developed in Athens or ancient Rome); Robert A. Dahl, Dilemmas of Pluralist Democracy (1982).

39. For some, democracy is participation; for others, democracy is deliberation; yet for others, democracy has independent, normative weight. For a sampling of democratic theory, see generally Norberto Bobbio, Democracy and Dictatorship (198i); Robert Dahl, A Preface to Democratic Theory (1956); Hans Kelsen, General Theory of Law and State (ig6i); Carlos Santiago Nino, Constitution of Deliberative Democracy (1996); Robert Post, Constitutional Domains: Democracy, Community, Management (1995). For an overview of these competing theories, especially as they relate to accountability in international politics, see Andrew Moravcsik, Is there a 'Democratic Deficit' in World Politics? A Framework for Analysis, 39 Gov't \& Opposit'n 336, 338-43 (2004) (discussing libertarian, pluralist, social democratic and deliberative notions of democracy).

40. See also David Held \& Mathias Koenig-Archibugi, Introduction to Special Issue of Miliband Conference on Global Governance and Public Accountability, London School of Economics and Political Science, May 17-18, 2002, reprinted in 39 Gov't \& Opposir's 125, 125 (2004) ("[T]here is agreement among democrats that wherever power is exercised there should be mechanisms of accountability."). In fact, Justice Anthony Kennedy recently noted that "accountability is the essence of democracy." Associate Justice Anthony Kennedy, Plenary Address, American Society of International Law Annual Meeting (March 30, 2006).

41. Grant \& Keohane, supra note 32, at 1 (Accountability "implies that some actors have the right to hold other actors to a set of standards, to judge whether they have fulfilled their responsibilities in light of these standards, and to impose sanctions if they determine that these responsibilities have not been met."); Held \& Koenig-Archibugi, supra note 40, at 127 ("Accountability refers to the fact that decision-makers do not enjoy unlimited autonomy but have to justify their actions vis-àvis affected parties, that is, stakeholders."); Stephan, supra note 16, at 684 ("[T] he kinds of accountability that matter are those by which the governed exercise control over their governors."). 
jority voting as the arbiter of democratic accountability. ${ }^{42}$ The "demos"-the "governed"--embrace periodic elections to choose "governors," delegate decisionmaking authority to such governors, and offer implicit consent to governors' decisions during the elected term. If governors make law that the governed deem distasteful, unsatisfactory, and/or illegitimate, the governed may choose not to reelect the governors, and the specter of such sanction maintains some semblance of accountability throughout the term.

Yet, one of the defining features of bottom-up lawmaking is that the lawmakers-in this case private insurance companies and low-level bureaucrats within ECAs - tend to be non-state actors and career civil servants rather than elected politicians. Thus, the actors who participate in bottom-up lawmaking do not stand for periodic re-election. Therefore, in the bottom-up lawmaking context, voting and elections are untenable routes to accountability.

However, accountability need not occur through republican-style voting for representatives. Consider the vast realm of administrative rulemaking in the United States, ${ }^{43}$ which stands as a legitimate part of our legal system even though the authors are often the bureaucrats and technocrats in the trenches who do not stand for re-election and who are not political appointees. Nonetheless, we create a variety of accountability mechanisms and feedback loops so that stakeholders retain some control over regulatory outcomes and, in turn, lawmakers remain accountable. ${ }^{44}$ For example, notice and comment rulemaking demands that agencies publish (and republish) proposed rules, accept comments from interested parties (this often includes oral hearings), and justify the ultimate rules in the context of the comments; ${ }^{45}$ the

42. DAHL, ON DEMOCRACY, supra note 38, at 37 (arguing that voting, in particular voting equality, is a cornerstone of all democracy); Thomas Jefferson, Letter to John Taylor (May 28, 1816), reprinted in Social and Political Philosophy 251-255 (John Somerville \& Ronald E. Santoni eds., 1963).

43. 5 U.S.C. $\$ 553$ (2000) (codifying informal, notice-and-comment rulemaking). Note that the administration of George W. Bush has aggressively used notice-and-comment rulemaking, especially in the environmental areas. See, e.g., Bruce Barcott, Changing All the Rules, N.Y. Times Mag., April 4, 2004, at 38.

44. I owe this insight in great part to the work of Laura A. Dickinson, Government for Hire: Privatizing Foreign Affairs and the Problem of Accountability Under International Law, 47 WM. \& MARY L. Rev. 135, 169-78 (although agency officials do not stand for election and re-election, administrative law and governance offer alternative mechanisms to create "feedback loops" that infuse varying degrees of accountability in the system of administrative law).

45. 5 U.S.C. \$553(b) (2000) (agencies must publish a notice of proposed rulemaking in the Federal Register, which includes: time, place and nature of rulemaking proceedings; legal authority for proposed rule; and "either terms or substance of proposed rule or a description of the subjects and issues involved); Id. at $\S 553$ (c) ("The agency shall give interested persons an opportunity to participate in the rule making through submission of written data, views, or arguments with or 
Freedom of Information Act grants all citizens access to government records regarding rules and rulemaking; ${ }^{46}$ and sunshine laws require that certain agency decisions be made in open meetings at published times. ${ }^{47}$

If administrative law operates as it should, agencies and agency lawmakers are not black boxes or impervious fortresses. To the contrary, we accept agency-enacted rules as a legitimate feature of our democratic system because the "governed" have meaningful opportunities to participate in governance. Administrative law assures that stakeholders not only know when lawmakers contemplate relevant regulatory change, as well as the nature and scope of such proposed changes, but also enjoy a well-paved avenue for participating in the lawmaking process-expressing opinions, offering expertise, and introducing alternative regulatory approaches.

Our vast web of administrative law is thereby premised on "participatory" (or perhaps even "deliberative" democracy) rather than "republican" democracy. ${ }^{48}$ In this account, opportunities for participation-opening space for a cacophony of voices - offer the "governed" a means to place pressure on the course of law. While such "pressure" is no guarantee that the "governors" will cede to the desires of the "governed,"49 such attenuated control nonetheless maintains adequate accountability to legitimate ensuing law..$^{50}$ Thus, participatory models of democracy close the gap between the "governed" and the "governors" by granting the former a proverbial seat at the lawmaking table, an opportunity to voice opinions and exercise persuasion.

If participation is a linchpin to accountability, then transparency (or the free flow of information) is the bridge to robust, meaningful participation. Imagine a world in which a regulatory entity, like the Berne Union, permitted nonmembers, like Brazil, to "participate" in its rulemaking processes, such as attend

without opportunity for oral presentation."); $I d$.at $\$ 706(2)$ (The agency must justify the ultimate rule with a "general statement of their basis and purpose" and a reviewing court may overturn the rule if it is "arbitrary, capricious, an abuse of discretion."). Some courts take an in-depth look (referred to as a "hard look") at whether an administrative agency has justified its ultimate rule visà-vis the comments that it receives. See generally Motor Vehicle Mfr. Ass'n v. State Farm Mut. Auto. Ins. Co., 463 U.S. 29 (1983).

46. Freedom of Information Act, 5 U.S.C. $§ 552$ (2000\& Supp. 2002).

47. The Government in the Sunshine Act, Id. at $\$ 552 \mathrm{~b}$.

48. See generally Robert Dahl, Who Governs?:Democracy and Power in an American City (2005); Dahl, ON Democracy, supra note 38; Levit, supra note 12, at n. 84.

49. In fact, on account of the rather attenuated relationship between "public participation" and public decision-making, Daniel Bodansky is relatively hesitant to tie participatory accounts of legitimacy to democratic accounts of legitimacy. Bodansky, supra note 31, at 614 .

50. See Grant \& Keohane, supra note 32, at 3 (discussing participation as a route to accountability (and thereby legitimacy)). 
Berne Union meetings, but did not publish meeting agendas or substantive rules. Without information regarding the scope, nature, and content of the proposed regulation, Brazil would not know which meetings to attend. And, even if Brazil wanted to "hedge its bets" by attending all meetings, it would be under-prepared to respond to regulatory challenges. Participation without information becomes nominal participation, and, to the extent that participation is the bridge to accountability, accountability thereby becomes nominal as well.

Thus, participation holds the promise of being real and robust only where there is transparency. Transparency is a window to unadulterated information. Information clearly delineates the "governed" by alerting stakeholders among the general public and forms the bedrock upon which stakeholders form opinions or regulatory alternatives. In addition, the integrity of stakeholders' opinions or proposals often calibrates "governors" alacrity in response to participation in the lawmaking process. Without transparency, honest, real participation is impossible; without participation, the "governed" must find alternative means to hold the "governors" accountable; and without accountability, law must find legitimacy outside of its constitutive processes. At a baseline, lawmaking processes must be transparent; there must be a free-flow of information if they are to comport with democratic norms. ${ }^{51}$

Of course, bottom-up lawmaking, particularly the type of regulatory bottomup lawmaking that this article contemplates, falls short in terms of transparency. Instead, opaque practices infuse bottom-up lawmaking and belie notions of transparent governance. As scholars and advocates, once we identify the sources of procedural woes, we tend to reach into our well-worn remedial toolbox in an attempt to patch such deficiencies. Thus, our unflinching response at this juncture would normally be to prescribe "transparency," to carve pre-fabricated "transparency" windows into bottom-up lawmaking processes. Yet, is this desirable? Or is this even possible? As for the first question, it is at least conceivable that transparency will open the "floodgates" too wide, permitting a surge of participation, in particular interest-group, rent-seeking demands that will unmoor bottom-up lawmaking from its practice-based roots, essentially transforming it into a process more akin to its top-down counterpart. As for the second question, we must at least contemplate whether our standard approach to transparency synchronizes with a bottom-up form of lawmaking.

51. While we are talking here more of "participatory" forms of democracy than "republican" forms of democracy, which, as discussed above, are not particularly relevant when the "governors" are non-elected, free-flow of information seems to be the linchpin to all forms of democracy. 
While transparency is quite a "buzz word" in international governance today, ${ }^{52}$ it will serve as a "legitimating" force only if it opens a meaningful window for stakeholders; otherwise, it is mere window-dressing. If the Berne Union were to publish the General Understanding on its website, but publish it after the members have concluded its terms, this type of transparency would not permit meaningful participation in the shaping of law. While subsequent input could presumably shape the future course of such law (i.e., lobbying for repeal or amendment), rules quickly become institutionalized and thereby "sticky," limiting the practical impact of post-hoc, as opposed to prior participation in the lawmaking process. Alternatively, if the Berne Union were to invite "stakeholders" or "civil society" to semi-annual meetings, but hold them in the world's most exclusive resorts (thereby making travel relatively expensive and inaccessible), ${ }^{53}$ or give only nominal notice of the meetings (again, when combined with the location this may make travel prohibitively expensive) ${ }^{54}$ or only have a few "slots" or "seats" allocated for outside participants, ${ }^{55}$ this type of "openness" would not foster robust participation. In the end, transparency is not an end in and of itself but must be a means to an end-that end being an inclusive, participatory process that supports accountability as the critical bridge between the "governed" and the "governors."

Furthermore, the very notion of transparency as a vehicle to meaningful participation presupposes a more classic lawmaking model where lawmaking is choreographed and linear, providing identifiable and productive moments when outsiders may assert pressure and influence over the course of law. In contrast, bottom-up lawmaking is an inherently organic process-messy and unpredictable in its spontaneity. All the transparency in the world may not actually engender meaningful participation because it simply may not be clear to stakcholders

52. Transparency has been of particular concern vis-à-vis the International Monetary Fund, the World Bank, and the World Trade Organization. See, e.g., Miles Kahler, Defining Accountability Up: the Global Economic Multilaterals, 39 Gov'r \& Opposit's 132, 143-48 (2004); Joseph J. Norton, International Financial Institutions and the Movement Toward Greater Accountability and Transparency: The Case of Legal Reform Programmes and the Problem of Evaluation, 35 INT'L L. 1443 (2001); Stephan, supra note 16, at 726-29. See Dickinson, supra note 44, at 168-79 (discussing transparency and transparency-enhancing mechanisms).

53. The Berne Union meetings are often held at exclusive, or relatively remote, destinations. See 2006 Berne Union Y.B. 121, at 170, for a list of the locations of semi-annual meetings since 1995.

54. See generally Levit, supra note 2, at 199 n.304.

55. Id. (with regard to OECD efforts to promote transparency and participation, noting that consultative sessions were short, offering only a few "seats" for members of civil society interested in participating, and that the notices of the sessions were short, offering limited opportunities for real, effective participation). 
when, where, or how to participate. Do we condemn the Berne Union members for not inviting NGOs and representatives from developing countries to also have drinks in the bar when they discussed the ideas that led to the Berne Union's creation? Obviously not. But when do these informal activities cross the line? When do they assume a conscious lawmaking posture? It is possible that only hindsight will tell. The challenge, of course, is how to add transparency to processes of an improvisational and unplanned character. And, depending on the particular context, it may be impossible to deploy our remedial arsenal, our standard answers to democratic deficits, within a bottom-up form of lawmaking.

Yet, if we surmount these very real challenges and imagine a bottom-up lawmaking community that practices meaningful openness, ${ }^{56}$ then bottom-up lawmaking actually emerges as profoundly democratic, at least when juxtaposed with the classic top-down account of international lawmaking. ${ }^{57}$ From Seattle to Doha, one of the recurring critiques of globalization (and concomitantly intergovernmental institutions) is that it exports decision making and lawmaking to a supranational sphere, creating intolerably wide physical and metaphysical space between the "governed" and the "governors." In this version, accountability is so attenuated as to be non-existent. Bottom-up lawmaking is quite the opposite; it is an inherently grounded process where international lawmaking ensues in the trenches, driven by those who have a stake in the regulatory outcome, and it simultaneously contemplates a type of horizontal, transnational web of those similarly situated around the globe. Certainly, if we understand democracy in the participatory sense, of direct "participation" of those governed in the governing process, or even in the deliberative sense, ${ }^{58}$ then bottom-up lawmaking feels organically democratic.

56. I recognize that participation in these lawmaking processes will not be truly inclusive and honestly representative of a plurality of ideas unless we account for asymmetries of power, imperfect information flows, unequal distribution of resources, or simply the chaos of lawmaking in such a decentralized, improvisational, and unpredictable way. But is this not also true of any lawmaking process, particularly those that occur on a transnational plane? Any time we journey from a hypothetical world, the friction of real-life intercourse creates an inevitable gap between imagined and hard reality. Why should we hold these bottom-up processes to a higher standard than state-driven lawmaking? See generally Moravcsik, supra note 39 at 338-43.

57. See W. Michael Reisman, The Democratization of Contemporary International Law-Making Processes and the Differentiation of Their Application, in Developments of International Law in Treaty Making 15 (Rüdiger Wolfram \& Volker Röben eds., 2005); Judith Resnik, Law's Migration: American Exceptionalism, Silent Dialogues, and Federalism's Multiple Ports of Entry, 115 YaLE L. J. 1564, 1666 (2006).

58. For an account of deliberative democracy, see Nino, supra note 39. 


\section{Output Legitimacy}

Thus far, the search for legitimacy-particularly accountability-anchored "input" legitimacy-holds limited promise. As private actors and non-elected offcials drive the bottom-up lawmaking process, elections-delegating lawmaking responsibility to elected representatives-are not the route to accountability. And, it is difficult to inject transparency, the linchpin to participatory forms of accountability, into non-choreographed lawmaking processes. While distasteful to some scholars,59 there are some who answer the legitimacy critique by eschewing "inputs" or "democratic processes" as the sole determinant of law's legitimacy. Rather, performance, or effective outputs-norms, rules, or law-may lend legitimacy to law.60 While "input" legitimacy focuses on tightening the connection and the congruence between the "governed" and the "governors," "output" legitimacy hinges on governors' expertise and alacrity as a means to strengthen trust in the governors.

From my experience in practice, I have watched bottom-up lawmaking in action, and I have even been a bottom-up lawmaker. ${ }^{61}$ In reality, bottom-up lawmaking communities demonstrate much ingenuity in the face of complex, technical issues. For instance, the General Understanding rules manage over a half-trillion dollars in trade per year ${ }^{62}$ and these rules inure not only to the benefit of large multinational corporations but also help small exporters gain relatively inexpensive credit and participate on a "level playing field." As bottom-up rules

59. See generally Fiss, supra note 26 (arguing that the use of "substantive outcomes" to legitimate law is "unexceptional," and further noting that "substantive outcomes may lead people to approve of the results," which is quite different from legitimacy, which requires "an independent set of criteria.").

60. See Bodansky, supra note 31, at 619-20 (noting that "expertise" is a source of legitimacy because "we judge an institution by its fruits"); Robert O. Keohane \& Joseph S. Nye, The Club Model of Multilateral Cooperation and Problems of Democratic Legitimacy, in Efficiency, Equity, And Legitimacy: The Multilateral Trading System at the Millennium 264, 285-87 (Roger B. Porter et al. eds., 2001) ("[T]he legitimacy of governments is not determined solely by the procedures on the input side. Substantive outputs also matter."); Anne-Marie Slaughter, Government Networks: The Heart of Liberal Democratic Order, in Democratic Governance \& International Law 199, 254 (Gregory H. Fox \& Brad R. Reth eds., 2000) ("[O]n the other hand, legitimacy may be conferred or attained independent of mechanisms of direct accountability-performance may be measured by outcomes as much as process. Courts, and even central banks, can earn the trust and respect of voters without being 'accountable' in any direct sense."); Anne-Marie Slaughter, Governing the Global Economy through Government Networks, in The Role of Law in INTERnArional Politics 177, 195 (Michael Byers ed., 2000).

61. See Levit, supra note 12, at n. 32.

62. See Chino, supra, note 10. 
are "indigenous," ${ }^{33}$ the fruits of those who day-in and day-out grapple with nitty gritty technicalities, it should come as no surprise that the solutions embodied therein often work quite well, especially from the vantage point of the crafters.

Yet, this "ends justify the means" approach is unsatisfactory, perhaps unsettling, on numerous levels. "Effectiveness"- the meeting of regulatory goals-is an inherently subjective inquiry, turning on perspective and vantage point. If Berne Union rules limit export subsidies and, thereby, maintain prices at a relatively high level, are the rules "effective" from the perspective of an importer or consumer in a developing country who cannot benefit from an ECA willing and able to subsidize the cost of imported goods? Likewise, from the perspective of Canada (Canadair), Berne Union-like limitations on export credit subsidies effectively "level" the playing field and protect government coffers. Nevertheless, I imagine that Brazil's (Embraer's) perspective is radically different. As a relatively late entrant into the aerospace market, Embraer likely views disproportionate government subsidies as the means to "level the playing field," as the only chance it has to compete with the established giants from the industrialized "north." Thus, when Brazil laments that industrialized (OECD) countries have "taken care of themselves" ${ }^{\prime 4}$ through Berne Union-like rules, Brazil essentially questions the substantive efficacy of such rules. "Effectiveness" thereby emerges as an elusively subjective standard, unsatisfactory in its post hoc relativity.

Even if it were possible to calibrate "effectiveness" using objective parameters, the "governed" must be able to measure outcomes against such objective standards. But how can institutions like the Berne Union open themselves to evaluation, showcasing their skill and experience, behind currently high and nearly impenetrable walls? How can the "governed" make such assessments if the rules themselves-in this case the General Understanding - are guarded as the most precious of state secrets? At a minimum, institutions like the Berne Union must become incrementally transparent, at least revealing substantive outcomes if not the deliberations leading to such outcomes, if they are to rely on "efficacy of outputs" as the arbiter of legitimacy. Yet, as discussed in the previous section, groups like the Berne Union are particularly resistant to even such limited, post-hoc transparency.

63. I borrow the term "indigenous law" from Marc Galanter, Justice in Many Rooms: Courts, Private Ordering, and Indigenous Law, 19 J. Leg. Pluralism 1, 17 (1981).

64. See supra notes $29 \& 30$ and accompanying text. 


\section{Self-Executing Legitimacy: Bottom-Up Lawmaking as a Route to Legitimacy}

After contemplating various sources of legitimacy - both on the "input" or "process" side and the "output" or "substantive outcome" side-are we left with the unsettling conclusion that bottom-up lawmaking is an illegitimate, albeit inevitable, route to law? If efficacy of regulatory outputs is a less-than-satisfactory route to legitimacy, and if it is impractical to expect bottom-up lawmaking to be an open, participatory process at all junctures, is bottom-up lawmaking a rogue, yet untamable, form of lawmaking? Perhaps not.

My current research - research on the transnational regulation of letters of credit via the International Chamber of Commerce Banking Commission ${ }^{65}$-is yielding data to suggest that an answer to the legitimacy critique may, in part, lie in the bottom-up lawmaking process itself; that perhaps "legitimacy" is a "selfexecuting" feature of bottom-up lawmaking. When informal lawmaking communities-like the Berne Union - step out and interact with officialdom (i.e., the WTO), which is an endemic part of the bottom-up lawmaking process, the modicum of transparency and accountability that these institutions have themselves adopted (largely at the prompting of the broader international community) tends to "rub off." In other words, the interinstitutional interplay inherent to bottom-up lawmaking may actually correct some of the legitimacy deficits in concrete ways (by creating "transparency windows" and enhancing "accountability capacity") and in less concrete ways (by shifting institutional consciousness).

As Berne Union rules develop behind opaque, fortress-like walls and seep beyond the insular lawmaking group, as they do via incorporation into the WTO Agreement on Subsidies, the WTO carves "transparency windows" for the Berne Union, and the Berne Union responds to global exposure and concomitant demands by enhancing its "accountability capacity." For instance, while the Berne Union's General Understanding is "secret," WTO documents are publicly available, in large part because the international community has demanded that the WTO inculcate "transparency" as an institutional norm. ${ }^{66}$ Although no longer parading as Berne Union rules, the WTO functionally "publicizes" such rules and carves "transparency windows" when it incorporates them into the Agree-

65. See Levit, supra note 14.

66. The WTO, largely in response to a vociferous critique of its opaque processes, now identifies "transparency," as one of the core principles of the international trading system and also has developed a comprehensive website which posts documents, interpretive material, and dispute settlement decisions. See, e.g., WTO, Understanding the WTO: Principles of the Trading System, http:// www.wto.org/english/thewto_e/whatis_e/tif_e/fact2_e.htm (last visited Mar. 20, 2007). 
ment on Subsidies. Likewise, as the WTO appropriates Berne Union rules within the Agreement on Subsidies, the congruence between the "governed" and the "governors" disintegrates, and the "governed" (yet disenfranchised) begin to demand access to the Berne Union as a means to participate in lawmaking processes and thereby hold the "governors" accountable. In response to similar criticism from disenfranchised constituents, formal lawmaking institutions, like the WTO and OECD, have institutionalized outreach to non-members as a means of enhancing accountability. ${ }^{67}$ Likewise, the Berne Union established the "Prague Club," a sister group of export credit insurers from the developing world, who do not meet the business-volume-driven membership requirements, but who nonetheless may observe and even participate in Berne Union deliberations. ${ }^{68}$

The Berne Union, through interface with formal lawmaking communities like the WTO, mimics approaches to transparency and accountability, importing legitimacy-enhancing practices and processes. Yet these innovations are not hermetically sealed within the institution; instead, they gradually infuse the Berne Union at the level of institutional consciousness, and it appears as if the Berne Union has at least started to internalize transparency and accountability as desirable institutional norms. For instance, for the first time, in late 2004, the Berne Union published a "Value Statement," in which it nods to the importance of transparency. ${ }^{69}$ And the Berne Union has recently revamped its website a bit, posting additional information and periodic press releases. ${ }^{70}$ The Berne Union admittedly falls short of the type of open, transparent governance that we have come to expect from democratically responsive institutions. Yet, shifts in institutional consciousness will undoubtedly propel the Berne Union to embrace transparency and accountability in diverse endeavors and, ultimately, to repair many, if not most, of the democratic deficits.

In interacting with official lawmaking institutions_an inherent part of the bottom-up lawmaking process-the Berne Union expanded its capacity to reach out to otherwise underrepresented constituencies and opened a more transparent

67. See OECD, Public Affairs Division, Public Affairs and Communications Directorate, Annual Report 2006 at 7, http://www.oecd.org/dataoecd/37/61/36511265.pdf.

68. See International Union of Credit and Investment Insurers, Berne Union, Prague Club, http://www.berneunion.org.uk/prague_club.htm (last visited Mar. 19, 2008).

69. See, e.g., Press Release, Berne Union, Three New Members Join the Berne Union (Oct. 2004), available at http://www.berneunion.org.uk/pdf/Press\%20Release\%20October\%202004.pdf (discussing a "Value Statement" which acknowledges the importance of "transparency").

70. See Berne Union, Press Releases, http://www.berneunion.org.uk/press-releases.html (last visited June 12, 2008). 
window into its processes. These concrete, institutional adjustments, in turn, gradually shifted the Berne Union's institutional consciousness in favor of such legitimacy-enhancing measures. Thus, "legitimacy" emerges as a self-executing feature of bottom-up lawmaking processes. What are the lessons or "take aways" from this conclusion?

The first is prescriptive. As lawyers, our inclination is to offer immediate programmatic fixes in the face of structural deficits in lawmaking processes. However, in the context of bottom-up lawmaking, "legitimacy" may be an evolutionary phenomenon, growing naturally and endogenously as the lawmaking process unfolds. We may not be able to breed "legitimacy" by simply superimposing cookie-cutter processes from classically democratic institutions. Yet, while informal lawmaking communities like the Berne Union may be relatively impervious to artificial attempts to inject transparency or enhance accountability, moments of interface with formal lawmaking communities nonetheless present fruitful "legitimating" opportunities. Thus, as the WTO imports Berne Union norms, it simultaneously exports transparency; as the WTO conveys Berne Union rules to a broader community, it, in turn, relays demands for input and participation. To the extent that we, as lawyers, have irrepressible "fix-it" instincts, we should focus on the "joints" - the interaction between informal and formal lawmakers. Moreover, we should recognize such moments of interface as ultimately conveying our efforts to introduce democratic practices within formal lawmaking institutions to the very informal communities that have been elusively impervious to our direct attempts.

The second lesson is normative. Legitimacy may be a red herring; as scholars, we need not excessively fixate on "legitimacy" because "legitimacy" may correct itself. As already discussed at length, "legitimacy" is self-executing - the interinstitutional interplay inherent to bottom-up lawmaking may actually correct, or ameliorate, some of the legitimacy deficits. Additionally, bottom-up lawmaking, the very process that presents legitimacy concerns in a particularly sharp and conceptually difficult way, may itself be self-limiting.

If the bottom-up lawmaking process naturally breeds transparency and accountability, then groups like the Berne Union will face (and indeed have faced) mounting demands for participation in the lawmaking process. Yet, in opening itself to "outsiders" and increasingly diversifying its previously homogeneous face, it becomes very difficult for groups like the Berne Union to continue the loop of practice-based, bottom-up lawmaking. To the extent that these lawmaking pro-

71. I borrow this appropriately descriptive term from Kal Raustiala \& David G. Victor, The Regime Complex for Plant Genetic Resources, 58 INT'L ORG. 277, 280 (2004). 
cesses are rooted in the technical experiences of niche communities, broad-based participation may be counterproductive by opening the floodgates to outside pressure, scrutiny, and demands, conceivably spelling the disintegration of the very practice-based, bottom-up lawmaking community that delivers relatively effective regulatory solutions. Indeed, there are signs that the Berne Union is shifting from a rulemaking, regulatory forum to a type of back-room, think tank-like appendage to the WTO, OECD, and World Bank, morphing into a laboratory for using private export credit transactions as a vehicle to balance the sometimes competing pulls of "free" or liberalized trade, on the one hand, and environmental and human rights norms, on the other hand..$^{72}$ In other words, over time, groups like the Berne Union may become dislodged from their practice-based roots and cede their lawmaking role to more formal, top-down lawmaking institutions.

Alternatively, if a group like the Berne Union rejected demands for participation, and thus tried to preserve the insular integrity of its homogeneous group, disaffected constituents could congeal in alternate, competing lawmaking communities. Of course, disparities in power, influence, and resources, particularly of the type that separate the developing from the industrialized world, may limit the ability of Brazil, for instance, to create an institution that meaningfully competes with the Berne Union. However, developing countries are not the only group that could challenge the Berne Union's niche hegemony. The private sector is aggressively deploying the Internet to create innovative alternatives to traditional export credit insurance products. ${ }^{73}$ And this type of competitive "molecularization" could, conceivably, challenge the Berne Union's normative relevance and relegate its bottom-up lawmaking role, and the attendant "legitimacy" grievances, to that of an outlier.

Thus, as my bottom-up lawmaking project matures, and as I start to look at groups like the Berne Union from a longitudinal perspective, I have come to understand that these groups often bear the seeds of their own limits, and possibly

72. See generally 2005 Berne UNION Y.B.

73. See Richard Barovick, The Changing World of Trade Finance, World Trade, April 2004, at 18. Additionally, the Internet revolution has spawned several companies who strive to harness electronic media to discover more efficient and less labor intensive alternatives to the letter of credit. TradeCard, Inc. is an online provider of financial settlement products (including products that function much like letters of credit) for international trade transactions. However, TradeCard does not run its transactions through a bank; instead a patented software program checks the documents and an export credit insurer essentially provides a "guarantee" in the face of buyer default. For more information, see www.tradecard.com. TradeCard has a few competitors, including Bolero, an AIG product, and a new product introduced by CIT. Gabriel Kahn, Financing Goes Just-in-Time, WALL St. J., June 4, 2004, at A10. 
devolution. Therefore, questions of legitimacy need not unduly preoccupy us. Perhaps, bottom-up lawmaking, and the inter-institutional dynamics that it unleashes, is at once self-correcting and self-limiting.

\section{Conclusion}

So in returning to the grand questions posed at the symposium-Democracy and the Transnational Private Sector-is the transnational private sector indeed an ascendant feature of international lawmaking? And, if so, does this create a threat to democracy? This article introduces one, but certainly not the only, way in which the private sector makes law-bottom-up transnational lawmaking. While this article explores one example in depth-the Berne Union's regulation of export credit insurance-I nonetheless argue that bottom-up lawmaking peppers our legal landscape in a profound and largely unacknowledged way. Thus, the private sector is a constitutive feature of much that we consider to be "law"both domestic and international. Therefore, if we, as scholars and advocates, hope to affect the course of law, we must be attentive to its roots and not deceptively complacent with what we see on the surface.

I am less concerned than others at this conference about the normative ramifications; perhaps, in the context of private transnational lawmaking, we unduly fixate on questions of legitimacy and democracy. Indeed, bottom-up lawmaking often is closed, exclusive, and club-like. Yet, democratic processes are not the sole source of legitimacy. And, even if they were, bottom-up lawmaking ostensibly bears self-correcting seeds. So, while some of the less-than-democratic practices embedded in bottom-up lawmaking uncomfortably tug at my notion of what law should be, what I am beginning to understand, and perhaps, from a democratic legitimacy vantage point appreciate, is that there appears to be a top to the bottom-up. 


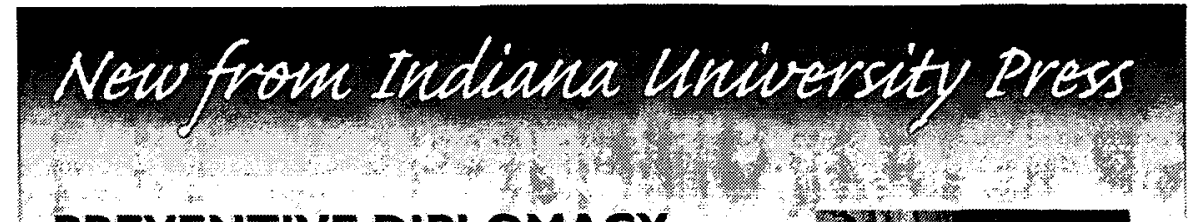

\section{PREVENTIVE DIPLOMACY AT THE UN}

Bertrand G. Ramcharan

Foreword by Leon Gordenker

The concept, practice, and achievements of preventive diplomacy at the UN.

United Nations Intellectual History Project Series Paper $\$ 24.95$ - Cloth $\$ 65.00$

\section{YOUTH AND THE CITY IN THE GLOBAL SOUTH}

Karen Tranberg Hansen in collaboration with Anne Line Dalsgaard, Katherine Gough, Ulla Ambrosius Madsen, Karen Valentin, and Norbert Wildermuth Innovative new research on globalization's impact on urban youth.

Tracking Globalization

Paper $\$ 24.95 \cdot$ Cloth $\$ 65.00$

\section{MADE IN MEXICO}

Zapotec Weavers and the Global Ethnic Art Market

\section{W.Warner Wood}

Oaxacan textiles from weaver to market.

Tracking Globalization

Paper $\$ 21.95 \cdot$ Cloth $\$ 55.00$
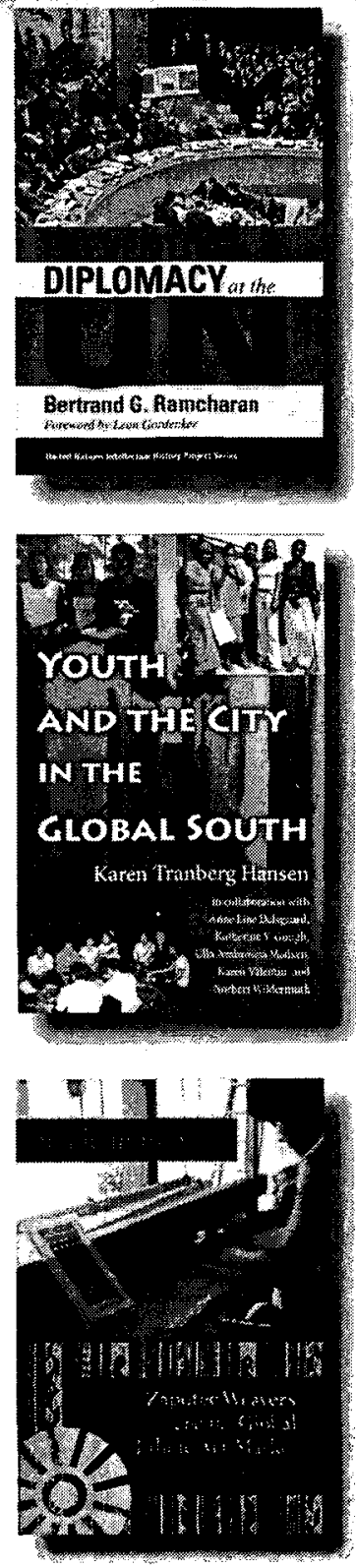